\title{
PENGENDALI ROBOT BERODA BERBASIS SENSOR TELEMETRI VOICE PATTERN RECOGNITION
}

\author{
Siswanto ${ }^{2}$, Dwi Arman Prasetya ${ }^{1}$, Nur Rachman ${ }^{2}$, Basitha F Hidayatulail ${ }^{1}$ \\ 1 Jurusan Teknik Elektronika UNMER Malang \\ ${ }^{2}$ Departemen Optik dan Hidrolik Lembaga Pengkajian Teknologi TNI-AD \\ Email : Sisoneto198911@gmail.com
}

\begin{abstract}
Abstrak
Pada perkembangan teknologi saat ini banyak dikembangkan jenis robot dengan kemampuan yang menarik adalah robot dengan pengendali suara manusia yang memanfaatkan teknologi pengenalan suara sebagai perintah untuk menggerakkan robot, sehingga robot bisa dikendalikan oleh suara manusia namun dalam hal ini dibutuhkan untuk keamanan perintah yang hanya mengenali suara user dengan menggunakan EasyVr, dan telepon seluler GSM dibutuhkan untuk mentransmisikan data suara dengan jarak jauh, karena proses pengiriman data menggunakan telepon seluler akan lebih efektif dan efisien. Easy Voice Commander sebagai perekam suara user sebanyak dua kali ucapan dengan kata yang sama dan modul EasyVR sebagai modul pengenalan suara yang selanjutnya perintah perintah akan diolah oleh mikrokontroler Arduino sehingga robot bisa bekerja dengan baik sesuai perintah suara dari user.
\end{abstract}

Kata Kunci: EasyVR, Arduino, Telepon seluler GSM

\section{Pendahuluan}

Kemajuan teknologi berkembang sangat pesat pada kehidupan manusia saat ini, khususnya pada bidang elektronika. Hal ini ditandai dengan adanya berbagai peralatan yang diciptakan dan dapat dioperasikan secara manual maupun otomatis. Dengan kemajuan teknologi saat ini maka berkembanglah suatu ilmu yang merupakan suatu pecahan dari ilmu elektronika yaitu dalam bidang robotika[1]. Salah satu jenis robot dengan kemampuan istimewa yang banyak menarik minat para pecinta robot untuk dikembangkan adalah robot beroda dengan pengendali suara. Dari perkembangan teknologi pengolahan sinyal suara ini munculah ide untuk membuat suatu sistem kendali robot yang efektif dengan menggunakan suara manusia seperti. Teknologi pengenalan suara merupakan salah satu teknologi biometrika yang tidak memerlukan biaya besar serta peralatan khusus[2][3]. Pada dasarnya setiap manusia memiliki suara yang khas atau ciri tertentu yang hanya dimiliki oleh dirinya sendiri. Suara merupakan salah satu dari bagian tubuh manusia yang unik dan dapat dibedakan dengan mudah. Seiring dengan perkembangan teknologi yang sebelumnya masih menggunakan radio control[4].

pengendali lainnya, sekarang sudah terdapat pengendalian secara otomatis dengan pengenalan suara. pengendali robot beroda dengan metode pengenalan suara tersebut untuk komunikasi data suara masih perlu ditingkatkan. Hal ini disebabkan pada proses pengiriman suara yang terlalu dekat, selain itu juga derau di sekitar masih sangat mempengaruhi dalam komunikasi pengiriman suara ke robot beroda[5][6]. Hal tersebut akan beresiko menghambat dan mempersulit diri untuk mengendalikan robot tersebut. dan kondisi seperti ini dapat diatasi dengan penambahan sistem pengiriman suara agar lebih jauh dan mudah untuk dikendalikan, sehingga proses pengiriman tersebut menjadi lebih baik. Berdasarkan uraian tersebut pada alat pengendali robot beroda yang biasanya masih menggunakan alat bantu ataupun radio kontrol sehingga dibutuhkan alat yang dapat mengendalikan robot tersebut dengan suara manusia dengan jarak yang lebih jauh, selain itu untuk mempermudah dan meningkatkan keakuratan perlu adanya peningkatan pada perangkat yang digunakan sebagai komunikasi antara user dengan robot beroda dengan menggunakan telepon seluler GSM, karena proses pengiriman 
dan penerimaan data menggunakan telepon seluler akan lebih efektif dan efisien[7][8]. Alat yang digunakan untuk mengenali suara yaitu menggunakan modul Easy Voice Recognition (EasyVR) sebagai proses untuk mengolah sinyal suara yang diteruskan ke Mikrokontroler Arduino Uno.Sehingga robot bisa bekerja dengan baik[9][10].

\section{Metode penelitian}

Metode adalah sebuah cara atau rangkaian yang di gunakan untuk menyelesaikan masalah. Metode yang digunakan dalam penelitian ini ada satu tahap, metode pola pengenalan suara ini digunakan untuk penyelesaian pengontrolan robot beroda. Dalam perancangan dan pembuatan alat terdapat variabel yang akan diuji Untuk mengetahui kualitas dari perancangan alat. maka dalam penelitian pola pengenalan suara ini ada 2 (dua) variabel yang akan diteliti dan dianalisa dengan harapan dapat mengetahui seberapa jauh sistem alat berjalan[11][12].

Delay merupakan waktu yang dibutuhkan suatu sistem untuk dapat bekerja dan merespon suatu perintah. Pada modul easyVr diisikan beberapa perintah untuk menggerakkan robot setiap perintah akan diuji berapa lama waktu yang dibutuhkan untuk robot dapat bergerak.

Salah satu bentuk pengenalan suara adalah pendekatan pengenalan pola yang terdiri dari dua langkah yaitu pembelajaran pola suara dan pengenalan suara melalui perbandingan pola. Tahap perbandingan pola adalah saat suara yang akan dikenal.

\section{Skema Arsitektur Perancangan}

Blok diagram keseluruhan sistem yang dirancang di bagi menjadi dua bagian, yaitu bagian pengirim data dan penerima data yang ditunjukkan dalam Gambar 2.1.

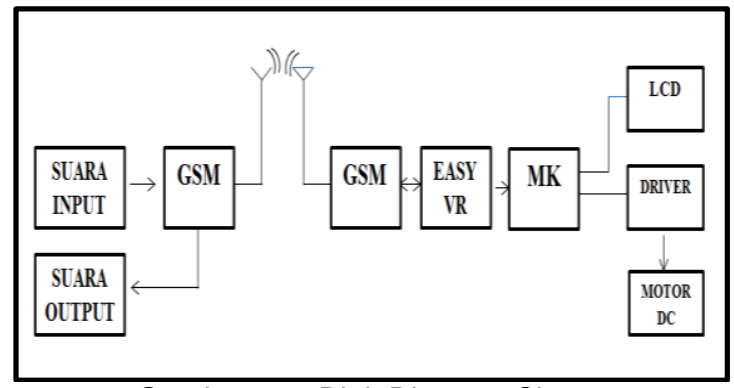

Gambar 2.1. Blok Diagram Sistem

\section{Perancangan Perangkat Keras}

\section{Rangkaian Mikrokontroler Arduino}

Pada rangkaian mikrokontroler Arduino Uno terdapat rangkaian pengirim dan penerima. Masing-masing pin berfungsi sebagai penghubung komponen satu dengan lainnya. Pada perancangan alat ini menggunakan mikrokontroler Arduino Uno sebagai pusat pengenalan perintah suara dan sebagai pusat kontrol penggerak robot. Masing-masing pin berfungsi sebagai penghubung komponen satu dengan lainnya. aktif low (0) untuk pin yang digunakan yaitu pin 12 dan 13 pada mikrokontroler Arduino Uno yang berfungsi untuk mengolah suara. Untuk menghubungkan komponen lainnya dapat ditunjukkan pada gambar 2.2.

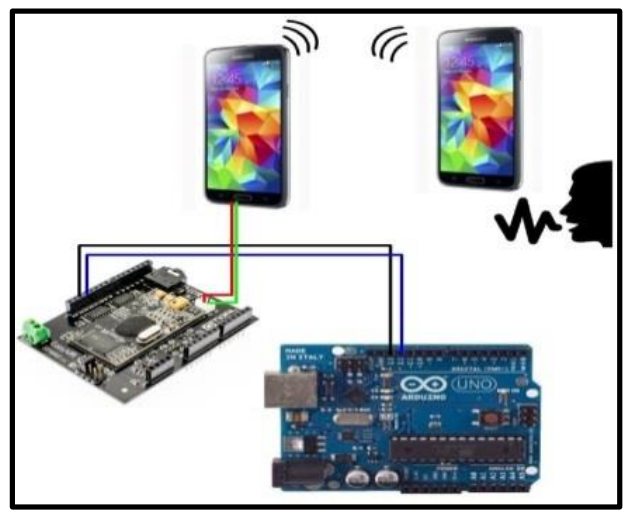

Gambar 2.2. Rangkaian Penyambungan Pin 


\section{Modul EasyVR}

EasyVR 2.0 dengan modul pengenalan suara multi fungsi yang dirancang untuk menambah serbaguna, ucapan dan pengenalan suara kemampuan yang kuat dan hampir efektif untuk aplikasi apapun. Pada EasyVR berkomunikasi secara serial dengan dua pin, sebuah pin sebagai $R X$ dan pin lainnya sebagai $T X$ dalam bentuk shield yang cocok dengan Arduino Uno. Pada modul easyVR sebagai pengenalan suara kurang bisa mendeteksi apabila di daerah yang banyak derau atau noise suara karena easy $V R$ ini sangat peka terhadap noise dan membutuhkan tempat yang tenang dan derau sangat mengganggu dalam pengenalan easyVR.

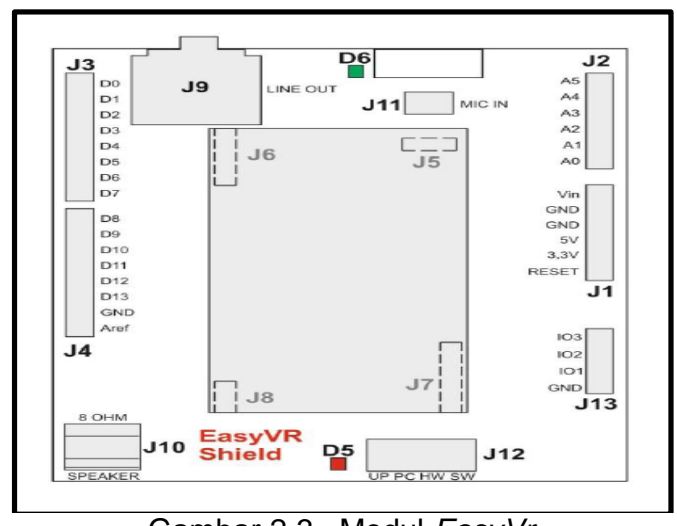

Gambar 2.3. Modul EasyVr

\section{Rangkaian $L C D$}

LCD (Liquid Crystal Display) yaitu jenis M1632 yang merupakan LCD dua baris dengan setiap barisnya terdiri atas 16 karakter. Gambar hubungan antara LCD dengan mikrokontroler ditunjukkan dalam Gambar 2.4

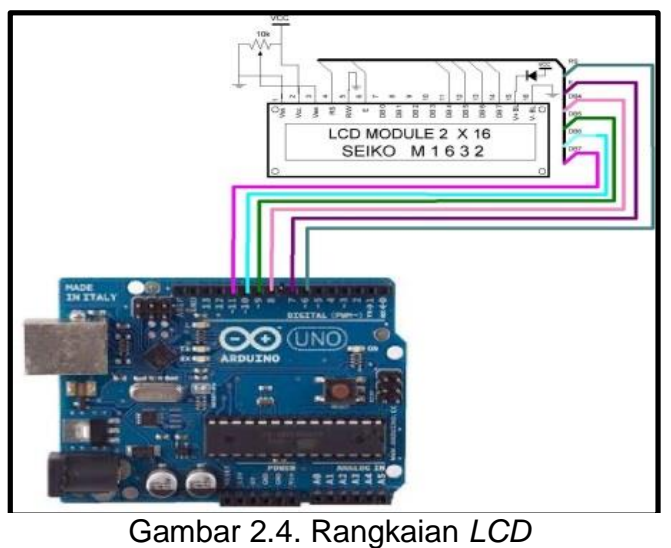

\section{Skema Arsitektur Sistem}

Perancangan dan pembuatan alat yang digabungkan menjadi satu sistem kerja terdiri dari tiga bagian besar yaitu bagian input atau masukan, bagian process atau pemroses dan bagian output atau keluaran.

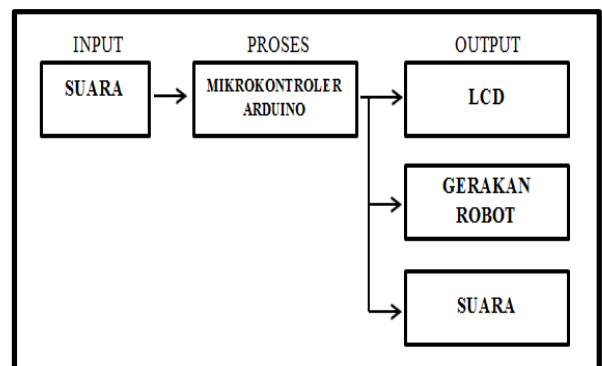

Gambar 2.5. Sistem Keseluruhan 


\section{Perancangan Perangkat Keras}

Perancangan Perangkat Lunak

Tahapan proses yang terdapat pada system ini meliputi proses pengolahan data dari modul EasyVR ke Arduino dan proses penggerakan robot. Semua proses tersebut dilakukan oleh perangkat lunak yang terdapat dalam mikrokontroler. Perangkat lunak ini tersusun dari perintah yang membentuk sebuah listing program.

Semua perintah program disusun secara terstruktur dalam beberapa sub yang secara khusus dapat menangani fungsi tertentu. Untuk Software mikrokontroler dibuat menggunakan program Arduino dengan menggunakan bahasa pemrograman yaitu bahasa pemrograman $\mathrm{C}$.

\section{Perancangan Sistem Pengenalan Suara Menggunakan Modul Easy $\mathrm{Vr}$}

Dalam perancangan ini bertujuan untuk mengambil sample suara yang akan disimpan didalam modul EasyVR. Untuk pengambilan suara dilakukan melalui PC dengan software bawaan dari EasyVR yaitu software EasyVR commander. Sampel suara yang akan digunakan adalah sebanyak enam kata seperti pada gambar 2.6

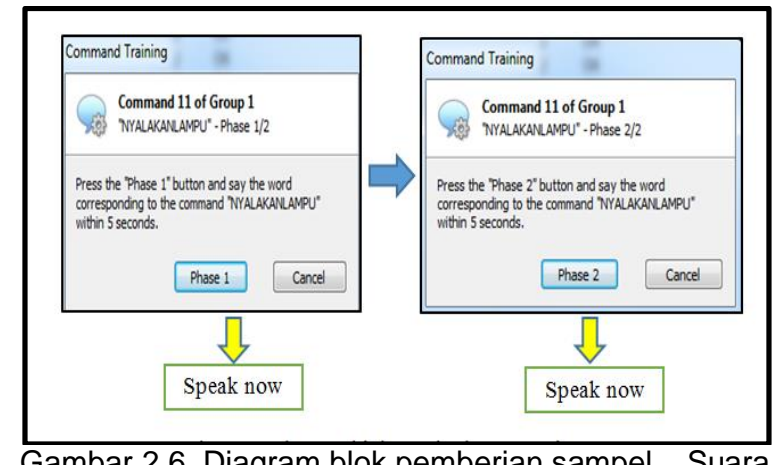

Gambar 2.6 Diagram blok pemberian sampel Suara
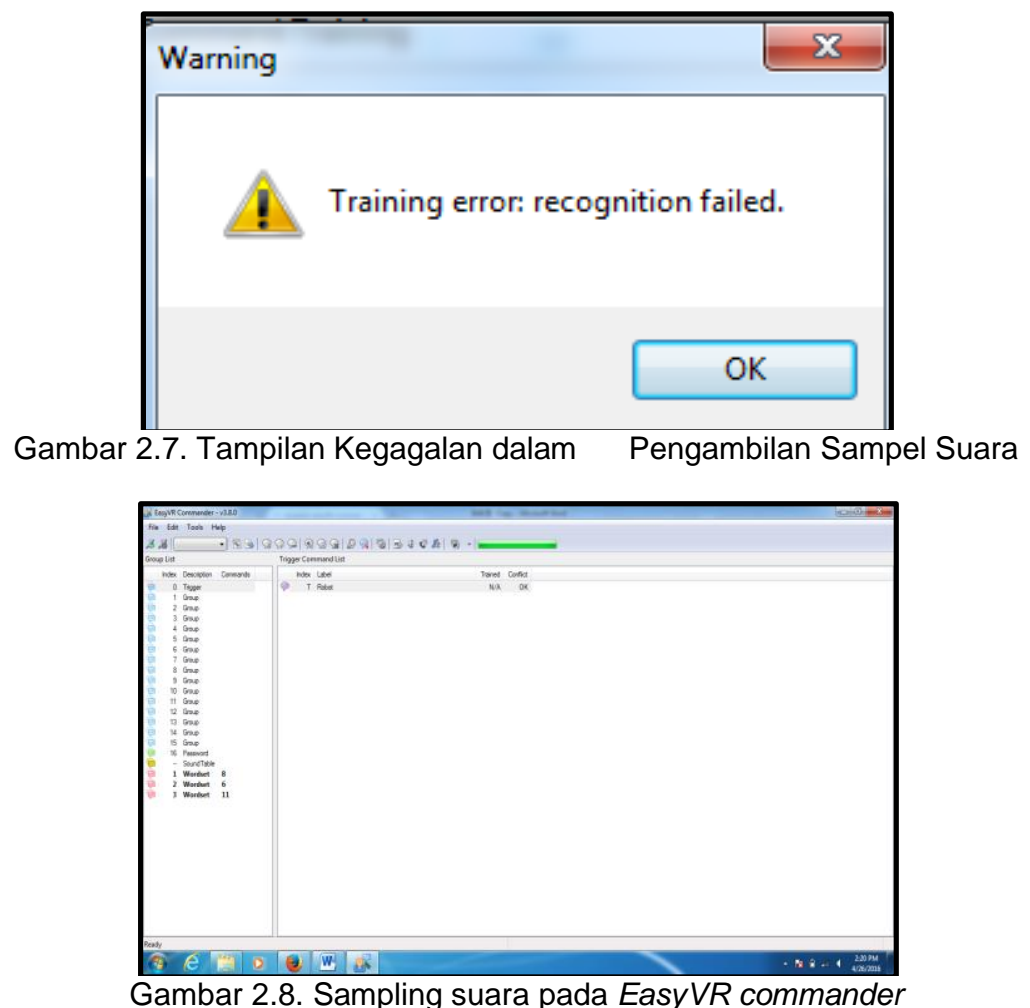

Gambar diatas menunjukan tampilan sampling suara pada EasyVR commander yang yang digunakan untuk melakukan recording. 


\section{Algoritma Sistem Kendali}

Diagram Alir (Flowchart)

Flowchart atau diagram alir adalah penggambaran secara grafik dari langkah-langkah dan urut-urutan prosedur dari suatu program. Flowchart merupakan bagan yang menunjukkan alur kerja atau apa yang sedang dikerjakan di dalam sistem secara keseluruhan dan menjelaskan urutan dari prosedur-prosedur yang ada di dalam sistem. Adapun perancangan sistem yang dibuat terlihat pada gambar 2.9

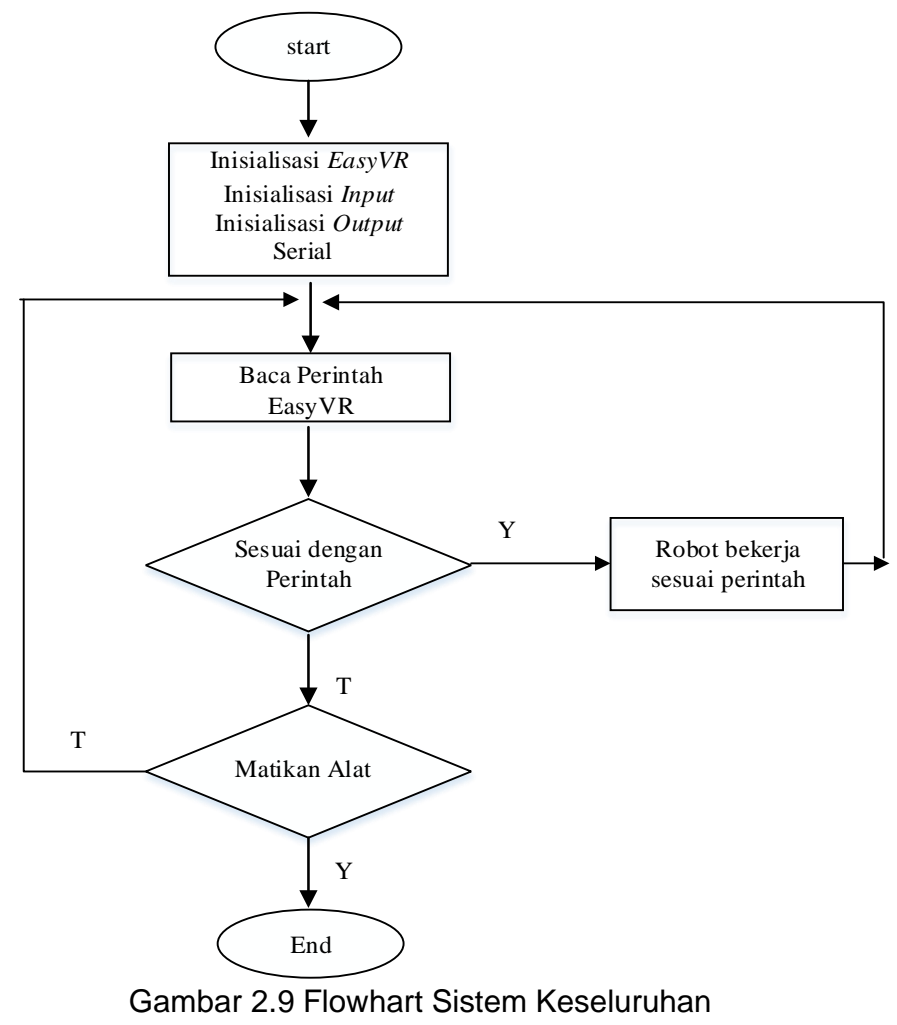

\section{Hasil dan Analisis}

\section{Pengujian dan Analisa Pola Suara}

Pada pengujian ini yang dilakukan adalah pengambilan bentuk karakter suara ,pengukuran frekuensi dan amplitudo, dan data yang mendekati suara perintah tersebut sesuai tujuh lafal kata yaitu maju, mundur, kanan, kiri, balik kanan, tembak dan putar yang hanya bisa diperintahkan oleh satu user. Masing-masing memiliki bentuk karakter suara yang berbeda. Berikut data hasil yang diperoleh dalam pengujian:

\section{Bentuk karakter suara "maju” pada saat perekaman pengujian}

Bentuk Karakter Suara “Maju” Pengujian ke 1

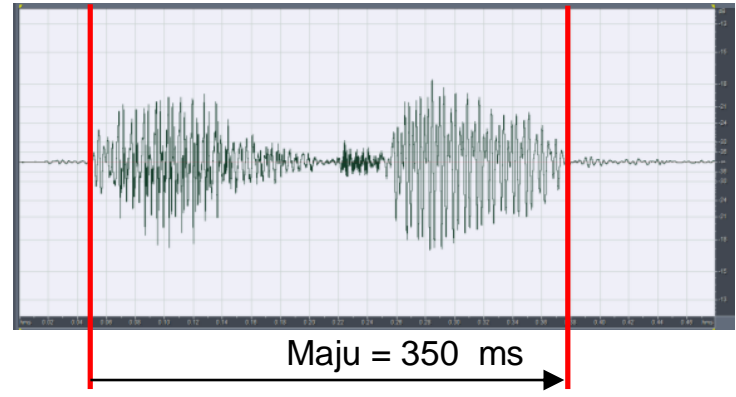

Gambar 3.1 Bentuk karakter pola suara "Maju” pada saat perekaman 
Pada gamabar 4.1. menunujukkan gambar bentuk karakter pola suara maju pada saat perekaman yang menunjukkan kata maju berintonasi $350 \mathrm{~ms}$, dan memiliki frekuensi $126.63 \mathrm{~Hz}$ dan mempunyai amplitudo puncak sebesar $-14.89 \mathrm{db}$ data tersebut diambil melalui frekuensi analisis yang terdapat di software adobe audition.

1. Bentuk Karakter Suara "Maju" Pengujian ke 1 (Gagal)

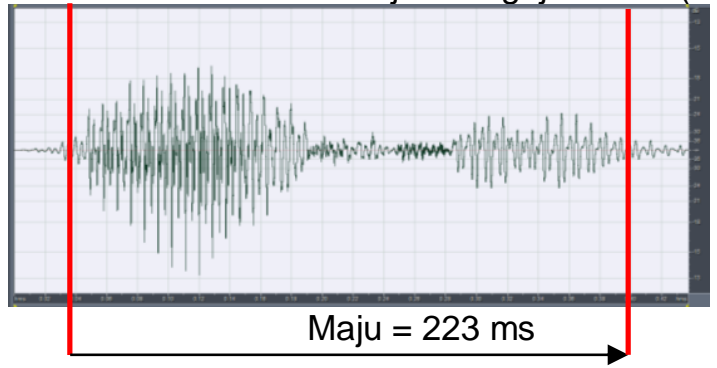

Gambar 3.2. Bentuk karakter pola suara "Maju" pengujian ke 1

Pada gamabar 3.2. menunujukkan gambar bentuk karakter pola suara maju pengujian ke 2 yang menunjukkan kata maju berintonasi $377 \mathrm{~ms}$, dan memiliki frekuensi $120.58 \mathrm{~Hz}$ dan mempunyai amplitudo puncak sebesar $-6.02 \mathrm{db}$ data tersebut diambil melalui frekuensi analisis yang terdapat di software adobe audition.

2. Bentuk Karakter Suara "Maju" Pengujian ke 2 (Berhasil)

3.

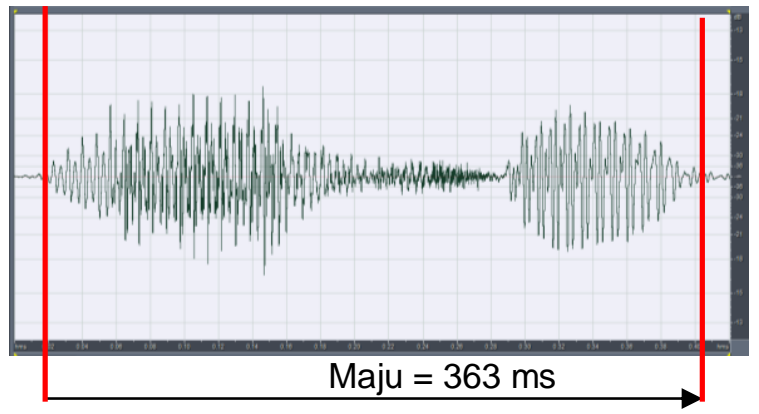

Gambar 2.3. Bentuk karakter pola suara "Maju" pengujian ke 3

Pada gamabar 4.3. menunujukkan gambar bentuk karakter pola suara maju pengujian ke 3 yang menunjukkan kata maju berintonasi $363 \mathrm{~ms}$, dan memiliki frekuensi $128.45 \mathrm{~Hz}$ dan mempunyai amplitudo puncak sebesar $-16.89 \mathrm{db}$ data tersebut diambil melalui frekuensi analisis yang terdapat di software adobe audition.

4. Bentuk Karakter Suara "Maju" Pengujian ke 3 (Gagal)

5.

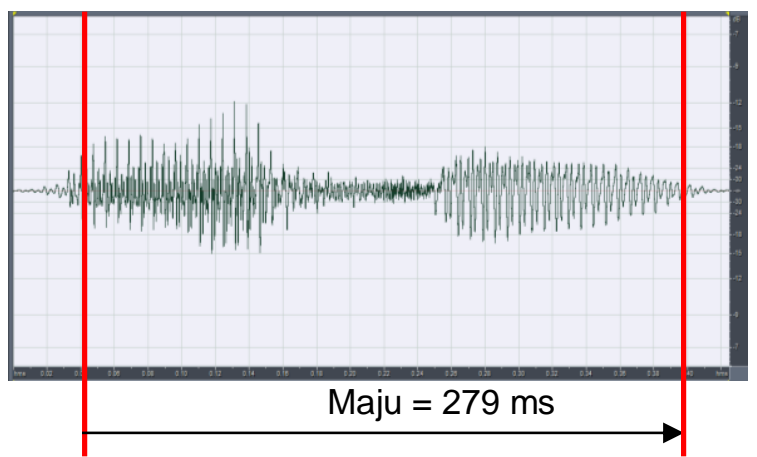

Gambar 2.4. Bentuk karakter pola suara "Maju" pengujian ke 5

\section{Perbandingan Data Pengujian Keseluruhan Pada Perintah.}

Tabel 1. Data Pengujian Frekuensi Perintah "Maju" 


\begin{tabular}{|l|l|l|l|l|l|}
\hline No & Pengujian & Waktu (ms) & $\begin{array}{l}\text { Amplitudo } \\
\text { puncak }(\mathrm{db})\end{array}$ & Frekuensi $(\mathrm{Hz})$ & Keterangan \\
\hline 1. & $\begin{array}{l}\text { Saat } \\
\text { Perekaman }\end{array}$ & 350 & -14.89 & 126.63 & Data Rekam \\
\hline 2. & 1 & 377 & -16.68 & 104.50 & Gagal \\
\hline 3. & 2 & 397 & -17.21 & 108.01 & Gagal \\
\hline 4. & 3 & 380 & -16.41 & 109.90 & Gagal \\
\hline 5. & 4 & 310 & -16.96 & 118.34 & Berhasil \\
\hline 6. & 5 & 363 & -16.89 & 128.45 & Berhasil \\
\hline 7. & 6 & 335 & -16.22 & 140.02 & Berhasil \\
\hline 8. & 7. & 387 & -16.72 & 164.32 & Berhasil \\
\hline 9. & 8. & 330 & -16.03 & 215.65 & Gagal \\
\hline 10. & 9. & 354 & 17.00 & 234.89 & Gagal \\
\hline 11. & 10. & 367 & 17.43 & 240.22 & Gagal \\
\hline
\end{tabular}

1. Frekuensi

a. Frekuensi terendah

Setelah melakukan pengujian perintah "maju" pada robot, frekuensi yang terendah terjadi pada pengujian ke 1 dengan frekuensi $104.50 \mathrm{~Hz}$, terjadinya frekuensi terendah dikarenakan pada saat memberikan perintah ke robot bernada rendah.

b. Frekuensi tertinggi

Setelah melakukan pengujian perintah "maju" pada robot, frekuensi yang tertinggi terjadi pada pengujian ke 10 dengan frekuensi $240.22 \mathrm{~Hz}$, terjadinya frekuensi tinggi dikarenakan pada saat memberikan perintah ke robot nada suara yang tinggi.

c. Frekuensi rata-rata yang direspon robot

Frekuensi rata-rata $=\frac{\text { Pengujian } 3+4+5+6}{4}=137.78 \mathrm{~Hz}$

d. Range frekuensi yang bisa diterima oleh Easy $V r=$ Nilai keberhasilan tertinggi - Nilai keberhasilan terendah $=164.32-118.34=45.98$

Setelah melakukan penelitian dan perhitungan terhadap frekuensi, pada perintah "maju" untuk menggerakkan robot pada pengujian dilakukan sebanyak sepuluh kali pengujian yaitu mencari nilai tengah dari frekuensi dasar atau frekuensi suara yang telah tersimpan pada modul easy $V r$ dengan nilai $126.63 \mathrm{~Hz}$, dari tiga nilai frekuensi terendah dan dari tiga nilai frekuensi tertinggi. Tiga nilai dari frekuensi terendah tersebuat yaitu $104.50 \mathrm{~Hz}, 108.01 \mathrm{~Hz}$ dan $109.90 \mathrm{~Hz}$, tiga nilai frekuensi tertinggi tersebut yaitu $215.65 \mathrm{~Hz}, 234.89 \mathrm{~Hz}$ dan $240.22 \mathrm{~Hz}$, dan terdapat empat nilai frekuensi tengah dari sepuluh pengujian tersebut yaitu $118.34 \mathrm{~Hz}, 128.45 \mathrm{~Hz}$, $140.02 \mathrm{~Hz}$, dan $164.32 \mathrm{~Hz}$. Dengan demikian membuktikan bahwa rata-rata frekuensi yang direspon robot yaitu $137.78 \mathrm{~Hz}$.

\section{Perbandingan Data Pengujian Keseluruhan Pada Perintah.}

Tabel 2. Data Pengujian Waktu Perintah Maju

\begin{tabular}{|l|l|l|l|l|l|}
\hline No & Pengujian & $\begin{array}{l}\text { Waktu } \\
(\mathrm{ms})\end{array}$ & $\begin{array}{l}\text { Amplitudo } \\
\text { puncak }(\mathrm{db})\end{array}$ & Frekuensi $(\mathrm{Hz})$ & Keterangan \\
\hline 1. & $\begin{array}{l}\text { Saat } \\
\text { Perekaman }\end{array}$ & 350 & -14.89 & 126.63 & Data Rekam \\
\hline 2. & 1 & 223 & -14.68 & 122.67 & Gagal \\
\hline 3. & 2 & 236 & -14.21 & 122.43 & Gagal \\
\hline 4. & 3 & 279 & -15.41 & 123.54 & Gagal \\
\hline 5. & 4 & 291 & -14.96 & 121.65 & Berhasil \\
\hline 6. & 5 & 302 & -14.89 & 122.00 & Berhasil \\
\hline 7. & 6 & 335 & -14.22 & 122.61 & Berhasil \\
\hline 8. & 7. & 466 & -14.72 & 122.38 & Berhasil \\
\hline 9. & 8. & 580 & -15.03 & 121.32 & Gagal \\
\hline 10. & 9. & 660 & -14.00 & 122.75 & Gagal \\
\hline 11. & 10. & 696 & -14.43 & 122.73 & Gagal \\
\hline & & & & & \\
\hline
\end{tabular}


1. Waktu

a. Waktu terpendek

Setelah melakukan pengujian perintah "maju" pada robot, waktu yang terpendek terjadi pada pengujian ke 1 dengan waktu 223 ms, terjadinya waktu terpendek dikarenakan intonsai perintah suara cepat.

b. Waktu terpanjang

Pada perintah "Maju" waktu yang terpanjang terjadi pada pengujian ke 10 dengan waktu $410 \mathrm{~ms}$, terjadinya waktu terpanjang dikarenakan intonasi perintah panjang.

c. Waktu rata-rata yang direspon robot

Waktu rata-rata $=\frac{\text { Pengujian } 4+5+6+7}{4}=348 \mathrm{~ms}$

d. Range waktu yang bisa diterima oleh Easy $V r$

Nilai keberhasilan tertinggi - Nilai keberhasilan terendah

$=466-291=175 \mathrm{~ms}$

Setelah melakukan penelitian dan perhitungan terhadap waktu, pada perintah "maju" untuk menggerakkan robot pada pengujian dilakukan sebanyak sepuluh kali pengujian yaitu mencari nilai tengah dari waktu dasar atau intonasi suara yang telah tersimpan pada modul easy $V r$ dengan nilai $350 \mathrm{~ms}$, dari tiga nilai waktu terendah dan dari tiga nilai waktu tertinggi. Tiga nilai dari frekuensi terendah tersebut yaitu $223 \mathrm{~ms}, 236 \mathrm{~ms}$ dan $279 \mathrm{~ms}$, tiga nilai waktu tertinggi tersebut yaitu $580 \mathrm{~ms}, 660 \mathrm{~ms}$, dan $690 \mathrm{~ms}$, dan terdapat empat nilai waktu tengah yang berhasil direspon robot dari sepuluh pengujian tersebut yaitu $291 \mathrm{~ms}, 302 \mathrm{~ms}, 335 \mathrm{~ms}$, dan 466 ms. Dengan demikian membuktikan bahwa rata-rata waktu yang direspon robot yaitu $348 \mathrm{~ms}$

\section{Perbandingan Data Pengujian Keseluruhan Pada Perintah.}

Tabel 3. Data Pengujian Amplitudo puncak

\begin{tabular}{|l|l|l|l|l|l|}
\hline No & Pengujian & Waktu $(\mathrm{ms})$ & $\begin{array}{l}\text { Amplitudo } \\
\text { puncak }(\mathrm{db})\end{array}$ & Frekuensi $(\mathrm{Hz})$ & Keterangan \\
\hline 1. & $\begin{array}{l}\text { Saat } \\
\text { Perekaman }\end{array}$ & 350 & -14.89 & 126.63 & Data Rekam \\
\hline 2. & 1 & 302 & -10.05 & 121.67 & Gagal \\
\hline 3. & 2 & 346 & -10.67 & 122.43 & Gagal \\
\hline 4. & 3 & 343 & -11.41 & 122.54 & Gagal \\
\hline 5. & 4 & 371 & -14.96 & 123.65 & Berhasil \\
\hline 6. & 5 & 329 & -15.22 & 122.00 & Berhasil \\
\hline 7. & 6 & 325 & -16.72 & 122.61 & Berhasil \\
\hline 8. & 7. & 341 & -16.89 & 123.38 & Berhasil \\
\hline 9. & 8. & 312 & -21.03 & 121.32 & Gagal \\
\hline 10. & 9. & 310 & -22.10 & 121.75 & Gagal \\
\hline 11. & 10. & 306 & -24.43 & 120.73 & Gagal \\
\hline
\end{tabular}

1. Amplitudo Puncak

\section{a. Amplitudo puncak terendah}

Setelah melakukan pengujian perintah "maju" pada robot, amplitude puncak yang terendah terjadi pada pengujian ke 1 dengan nilai $-10.05 \mathrm{db}$, terjadinya amplitudo puncak terendah dikarenakan pada saat memberikan peintah ke robot suara perintah kuat.

b. Amplitudo puncak tertinggi

Setelah melakukan pengujian perintah "maju" pada robot, amplitude puncak yang tertinggi terjadi pada pengujian ke 10 dengan nilai $-24.43 \mathrm{db}$, terjadinya amplitudo puncak tertinggi dikarenakan pada saat memberikan perintah ke robot suara perintah lemah.

c. Amplitudo puncak rata-rata yang direspon robot

Amplitudo puncak rata-rata $=\frac{\text { Pengujian } 4+5+6+7}{4}=-15.94 \mathrm{db}$ 
Setelah melakukan penelitian dan perhitungan terhadap amplitudo puncak, pada perintah "maju" untuk menggerakkan robot pada pengujian dilakukan sebanyak sepuluh kali pengujian yaitu mencari nilai tengah dari amplitudo puncak dasar atau amplitudo suara yang telah tersimpan pada modul easy $V r$ dengan nilai $-14.89 \mathrm{db}$, dari tiga nilai amplitudo terendah dan dari tiga nilai amplitudo tertinggi. Tiga nilai dari amplitudo terendah tersebut yaitu $-10.05 \mathrm{db}$, $-10.67 \mathrm{db}$ dan $-11.41 \mathrm{db}$, tiga nilai amplitudo tertinggi tersebut yaitu $-21.03 \mathrm{db},-22.10 \mathrm{db}$, dan $24.43 \mathrm{db}$, dan terdapat empat nilai amplitudo tengah yang berhasil direspon robot dari sepuluh pengujian tersebut yaitu $-14.96 \mathrm{db},-15.22 \mathrm{db},-16.72 \mathrm{db}, 16.89 \mathrm{db}$. Dengan demikian membuktikan bahwa rata-rata waktu yang direspon robot yaitu $-15.94 \mathrm{db}$.

\section{Kesimpulan}

Setelah melalui tahap perencanaan, pembuatan dan pengujian alat "Pengenalan Suara menggunakan modul Easy Vr dan Telepon seluler sebagai media transmisi data ". Pada saat pengambilan simple suara pada modul Easy $\mathrm{Vr}$ dilakukan sebanyak 2 kali pengucapan dengan kata-kata yang sama. Robot beroda dapat mengenali suara dari user dengan metode pengenalan pola suara untuk menggerakkan robot sesuai perintah dengan 6 lafal yaitu maju, mundur, kanan, kiri, tembak, dan balik kanan, dari hasil pengujian, derau sangat mempengaruhi dalam sistem pengendalian robot semakin tinggi derau robot semakin sulit untuk merespon perintah. Frekuensi Suara dasar yang terekam easy Vr yaitu $126.63 \mathrm{~Hz}$. Frekuensi terendah $104.50 \mathrm{~Hz}$, frekuensi tertinggi $240.22 \mathrm{~Hz}$, frekuensi rata-rata $137.78 \mathrm{~Hz}$. dan mempunyai range dari yang terendah sampai range tertinggi yaitu $45.98 \mathrm{~Hz}$. Waktu terpendek $223 \mathrm{~ms}$, waktu terpanjang $140 \mathrm{~ms}$, waktu rata-rata $348 \mathrm{~ms}$ dan mempunyai range dari yang terpendek sampai range yang terpanjang $175 \mathrm{~ms}$. Amplitudo puncak terendah $-10.05 \mathrm{db}$, amplitude puncak terringgi $-24.43 \mathrm{db}$, rata-rata $-15.94 \mathrm{db}$. Yang sering terjadi robot tidak bisa merespon perintah dari user karena intonasinya yang berbeda diasaat memberikan simple dan pada waktu memberikan perintah.

\section{References}

[1] A. Widiyanto and N. Nuryanto, "Rancang Bangun Mobil Remote Control Android dengan Arduino," Creat. Inf. Technol. J., 2018.

[2] E. H. Helmi guntoro, Yoyo Somantri, "Rancang Bangun Magnetic Door Lock Menggunakan Keypad Dan Solenoid Berbasis Mikrokontroler Arduino Uno," Electrans, 2013.

[3] A. F. Hastawan, A. Hidayatno, and R. R. Isnanto, "Deteksi Sudut Menggunakan Kode Rantai Untuk Pengenalan Bangun Datar Dua Dimensi," Transmisi, 2013.

[4] R. Yuwono, I. Mujahidin, A. Mustofa, and Aisah, "Rectifier using UFO microstrip antenna as electromagnetic energy harvester," Adv. Sci. Lett., 2015.

[5] R. Bimarta, A. E. Putra, and A. Dharmawan, "Balancing Robot Menggunakan Metode Kendali Proporsional Integral Derivatif," IJEIS (Indonesian J. Electron. Instrum. Syst., 2015.

[6] M. F. Rahmat and M. Md Ghazaly, "Performance Comparison Between PID and Fuzzy Logic Controller In Position Control System Of DC Servomotor," J. Teknol., 2013.

[7] I. Mujahidin, "Directional $1900 \mathrm{MHz}$ Square Patch Ring Slot Microstrip Antenna For WCDMA," JEEMECS (Journal Electr. Eng. Mechatron. Comput. Sci., 2019.

[8] J. T. Elektro, F. T. Industri, and U. K. Petra, "Kontrol PID Untuk Pengaturan Kecepatan Motor DC Dengan Metode Tuning Direct Synthesis," vol. 4, no. 1, pp. 10-17, 2004.

[9] R. L. Singgeta and Sompie, "Rancang Bangun Robot Boat Navigasi Tanpa Awak," EJournal Tek. Elektro Dan Komput., 2013.

[10]A. Mukti, O. D. Nurhayati, and E. D. Widianto, "Rancang Bangun Sistem Kontrol Robot Line Follower Menggunakan Logika Fuzzy," J. Teknol. dan Sist. Komput., 2017.

[11]R. A. Brooks, "A Robust Layered Control System For A Mobile Robot," IEEE J. Robot. Autom., 1986.

[12]S. Faro, "Pelvic inflammatory disease," in Clinical Gynecology, Second Edition, 2015. 


\section{Daftar Riwayat Hidup}

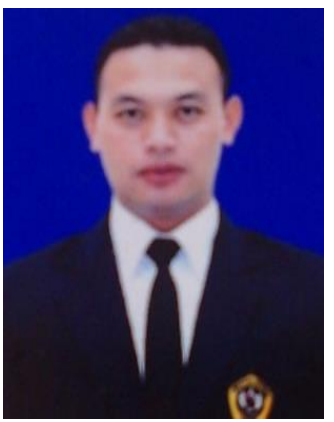

Siswanto, lahir di Magelang 25 Nopember 1989, agama Islam. Penulis menamatkan pendidikan di MI Trimaja mertoyudan Magelang 2002. Setelah itu penulis melanjutkan pada jenjang pendidikan SLTP di SMP Persatuan Mertoyudan Magelang lulus pada tahun 2005. Pada tahun 2005 penulis melanjutkan pendidikan di SMK Muhammadiyah 1 Mungkid Magelang lulus pada tahun 2008. Atas anugerah ALLAH SWT maka penulis pada tahun 2013 dapat melanjutkan pendidikan S1 di Jurusan Teknik Elektro UNIVERSITAS MERDEKA Malang hingga saat ini. 